\title{
When in Rome? \\ Examining the Institutional Determinants of Agglomeration for Foreign Entrants
}

\author{
XAVIER MARTIN \\ Tilburg University (B 1130) \\ P.O. Box 90153 \\ 5000 LE Tilburg \\ The Netherlands \\ Ph.: + 3113 466-8098 \\ Fax: +31 13 466-8354 \\ E-mail: xmartin@uvt.nl \\ ROBERT SALOMON \\ Stern School of Business \\ New York University \\ 44 W. $4^{\text {th }}$ St., KMC 7-59 \\ New York, NY 10012 \\ Ph.: 212-998-0223 \\ Fax: 212-995-4234 \\ E-mail: rsalomon@stern.nyu.edu \\ ZHEYING WU \\ Marshall School of Business \\ University of Southern California \\ Bridge Hall 306 \\ Los Angeles, CA 90089-0808 \\ Ph: 213-740-8514 \\ Fax: 213-740-3582 \\ Email: zwu@usc.edu
}

Version: March 5, 2008 


\title{
When in Rome? \\ Examining the Institutional Determinants of Agglomeration for Foreign Entrants
}

\begin{abstract}
Although scholars from various disciplines have examined the antecedents to foreign direct investment (FDI) location choice, we understand less than we should about how the institutional environment of both the host and home country impact those decisions. To fill that gap, this paper examines institutional factors impact the agglomeration patterns of foreign entrants. We theorize that institutional contexts characterized by collectivist cultures, as well as economic and political uncertainty, encourage foreign entrants to locate within existing geographic agglomerations. To test our hypotheses, we empirically examine the location patterns of 181 foreign plant investments made by 61 parent firms across 22 countries in the global semiconductor industry. The findings reveal that foreign entrants are more likely to agglomerate in host countries characterized by collectivist cultures and by political and economic uncertainty. Home country characteristics had very little impact on the agglomeration decision of the foreign entrants. These results enrich traditional literature on FDI location choice by suggesting that the decision to agglomerate is context-dependent. Moreover, when choosing a location within a given country, foreign entrants are more likely to adapt to characteristics of the host country.
\end{abstract}

Keywords: Location Choice; Agglomeration; FDI; International Business 


\section{INTRODUCTION}

Location choice is an important element of strategy for multinational firms (Dunning, 1988). Foreign entrants must not only carefully consider which country markets to enter, but once they have decided on which country they will enter, they must choose a particular locale for their investment. The location that firms choose within a given country impacts their access to local endowments such as raw materials and human capital. It also impacts their access to information, and the nature of competition they will face. In addition, locating in certain areas exposes firms to risks and uncertainties. Not surprisingly therefore, location choice stands to have a substantial impact on the performance, growth and survival of multinational firms.

Although scholars from various disciplines recognize the importance of the location choices of foreign entrants within host countries, most existing studies focus on the firm-level factors that drive those decisions (Shaver \& Flyer, 2000; Chung \& Song, 2004; Nachum \& Wymbs, 2005). Few assess the impact of institutional factors on FDI location choice (see Benito \& Gripsrud, 1992; Henisz \& Delios, 2001 for notable exceptions), and those that do generally focus on which countries to enter rather than whether to agglomerate. We therefore understand less than we should about why firms choose certain locations within a given country, and how institutional environments impact those decisions. To fill this gap, we examine the institutional determinants of location choice for foreign entrants into given host countries. Following prior studies, the dependent variable of interest is the decision to agglomerate - i.e., whether to locate within a geographic cluster of industrial activity. We assert that foreign entrants are influenced by two sets of institutional forces: from the host country and the home country. Our goal is to shed some light on the relationships between home and host country institutional factors, and a foreign firm's incentives to agglomerate. 
In order to examine these relationships, we analyze the location pattern of 181 foreign plant investments made by 61 firms across 22 countries from 1975 to 2004 in the global semiconductor industry. We are interested in the location patterns of foreign entrants to see whether, and how, the institutional environments across both the home and host countries affect a foreign entrant's decision to agglomerate. Consistent with our theory, we find that foreign entrants are more likely to agglomerate when the host country is characterized by a collectivist culture and by political and economic uncertainty. Home country effects had little impact. The findings suggest that the institutional environment in the host country impact a firm's incentives to agglomerate, and demonstrate that foreign firms are more likely to adapt to environmental conditions in the host country when making such decisions.

This paper makes several contributions to the extant strategy and international business literatures. First, this study sheds light on the institutional determinants of FDI location choice. Although prior work shows that firm-level factors impact location decisions, we demonstrate that, controlling for those factors, institutional factors also matter. Moreover, with respect to the location choice of foreign entrants, host country factors influence their location preference more than home country factors. To our knowledge, no study has explicitly examined the impact of host and home country institutional factors on the agglomeration decision. Second, most empirical studies of agglomeration generally use data from a single economy. In this study, we take advantage of crosscountry panel data. We can therefore identify and control for empirical regularities in firm behavior across an array of host and home countries over time. Such cross-country data is sorely needed to advance our understanding of international business phenomena (Martin, Swaminathan, \& Tihani, 2007). Finally, few studies have simultaneously examined the macro- and micro- level determinants 
of firm location choices. While we are specifically interested in the institutional determinants of location choice, we control for both environmental (macro) and firm-specific (micro) characteristics.

\section{LITERATURE REVIEW}

Commitments that firms make to geographic locations are substantial, long-lasting, and often irreversible. Not surprisingly therefore, location choices can have enduring implications for firm performance. Because firms are impacted by the resources available within its local environment, firms tend to carefully weigh location decisions.

Recognizing this, scholars from various disciplines have long examined the location pattern of firms. Economics scholars have predominantly focused on what causes firms to select particular geographical locations in the first place. On the input side, economic geographers note that resource endowments and the availability (scarcity) of human capital can facilitate (restrict) a firm's development. For this reason, firms should favor sites that are rich with various input factors in order to minimize costs (Ghosh \& Rushton, 1987; Weber, 1929). Work in industrial organization, by contrast, maintains that firms should maximize their proximity to customers, yet keep their distance from competitors so as to avoid head-to-head competition (Hotelling, 1929).

Building upon this latter insight, research on firm location choice in the strategy literature has centered on whether firms choose to locate geographically proximal or distal to one another. This phenomenon has been referred to as agglomeration. Agglomeration, or the geographical clustering of firms, can have both positive and negative consequences for firms. On the one hand, an agglomeration of firms can generate beneficial externalities. For example, Marshall (1920) argued that the clustering of similar firms creates a pool of specialized labor that can be shared among members of the agglomeration. Additionally, firms in the agglomeration benefit from specialized 
suppliers that increase the overall competitiveness of the industry (Porter, 2000). Moreover, locating close to similar firms affords them the opportunity to share knowledge with others or absorb knowledge through competitive spillovers (Marshall, 1920). Firms can learn from their competitors' experiences, and competition can improve the performance of firms within the agglomeration. Therefore, such positive externalities motivate firms to agglomerate.

On the other hand, scholars note that agglomerating does not come without costs. As the number of firms requiring similar resources in an agglomeration increases, competition intensifies, which leads to a corresponding increase in firm failure (Hannan \& Carroll, 1992; Hannan, Carroll, Dundon, \& Torres, 1995; Fischer \& Harrington, 1996). Competition therefore provides a disincentive to agglomerate (Baum \& Haveman, 1997). In addition, firms in an agglomeration do not uniformly benefit from knowledge spillovers. Firms also contribute to the knowledge pool within the agglomeration. Therefore, firms with superior technology have an incentive to locate away from the agglomeration to avoid information leakage and the potential for costly spillovers to competitors (Shaver \& Flyer, 2000; Nachum \& Wymbs, 2005).

Location decisions take on heightened importance for foreign entrants, as they must make decisions about countries in which they often lack experience, and in situations in which they are at an informational disadvantage. Foreign firms face disadvantages relative to domestic firms due to information asymmetries, cultural differences, coordination difficulties, and local biases (Zaheer, 1995; Caves, 1996; Martin \& Salomon, 2003a). As a result, foreign firms generally have a higher failure rate than domestic firms (Zaheer \& Mosakowski, 1997).

With respect to the agglomeration decisions of foreign firms, what little empirical work that exists suggests that the location decisions of foreign entrants are subject to many of the same forces that impact domestic firms (e.g., Woodward \& Rolfe, 1993; Braunerhjelm \& Svensson, 1996; 
Barrell \& Pain, 1999; Shaver \& Flyer, 2000; He, 2002; Chung \& Song, 2004; Nachum \& Wymbs, 2005). In contrast to existing studies however, we argue that in addition to the traditional firm-level drivers of agglomeration, foreign entrants also factor in the institutional environments of the host and home countries when deciding whether to agglomerate.

The interesting issue when considering the location decisions of foreign firms is that in contrast to domestic firms, foreign entrants are from nations where the institutional environments often differ from those in the host country. While purely domestic firms face a constant national context, foreign firms face a more complex environment. Subsidiaries of multinational firms are influenced by the forces within the destination country, and as such, subject to the demands of the local market. However, foreign subsidiaries are managed by a parent that often originates from a country with a very different institutional context (Rosenzweig \& Singh, 1991; Westney, 2005). Not surprisingly, the competitive context in the parent's home country shapes the strategy of the subsidiary (Erramilli, 1996). Foreign subsidiaries are therefore subject to various pressures emanating from both the home, and host, countries. The question that follows is whether foreign firms, in deciding whether to agglomerate, adapt to those forces in host country, or preserve patterns of behavior exhibited in their home country.

In summary, research in international business has examined the antecedents to agglomeration. Similar to the domestic literature on agglomeration, studies find that many of the drivers of agglomeration are similar across foreign and domestic contexts. However, little attention has been paid to the institutional determinants of the agglomeration decisions of foreign firms. Moreover, there has been little examination of the role that the institutional environment of both the home country and the host country play in the agglomeration decision of foreign entrants. In the next 
section, we develop hypotheses regarding how institutional factors are likely to affect a multinational's incentives to agglomerate.

\section{THEORY}

Firms are embedded in a social and institutional context. As a product of the social and institutional contexts in which they are born, firms are inherently imprinted with societal and institutional norms. Conforming to these norms legitimizes firms by helping to justify their existence and increasing their chances for survival (DiMaggio \& Powell, 1983; Meyer \& Rowan, 1977). Thus, the social and institutional contexts deeply influence firm behavior.

One important factor in the social context is national culture. Culture normalizes the behavior of organizational actors within societies (Hofstede, 2001). Though prior studies have investigated the impact of national culture on firm behavior and foreign entry (Hofstede, 1985, 1994; Kogut \& Singh, 1988; Hofstede, Van Deusen, Mueller, Charles, \& Business Goals Network, 2002), few address the impact of culture on location choice. However, one such study finds that culture indeed impacts location choice (Martin, Salomon, \& Wu, 2007). In an examination of agglomeration across various countries, Martin, Salomon and $\mathrm{Wu}(2007)$ find that firms are more likely to agglomerate in countries characterized by collectivist cultures. ${ }^{1}$

There are two main explanations for why firms in collectivist (versus individualist) countries are more likely to agglomerate (Salomon \& Wu, 2007). First, collectivist cultures place a greater emphasis on a subordination of individual goals to group goals, and the adoption of group norms (Hofstede, 2001; Morris, Davis, \& Allen, 1994; Triandis, 1995). Firms in a

\footnotetext{
${ }^{1}$ Though national culture has multiple dimensions besides individualism/collectivism (i.e., uncertainty avoidance, masculinity, power distance, and long-term orientation) those authors did not find any relationship between dimensions other than individualism/collectivism and agglomeration.
} 
collectivist culture are likely to ceremonially follow norms set by the majority (DiMaggio \& Powell, 1983). As a result, in countries characterized by collectivism, firms obtain greater legitimacy by joining an agglomeration because it is regarded as rational, efficient, and legitimate (Meyer \& Rowan, 1977). By contrast, in individualist cultures, individual decisions are generally made independently of larger group interests, norms, and goals. In such cultures, deviation from group norms is more socially acceptable. Therefore, choosing a location far away from an agglomeration is more likely to be viewed as socially legitimate as compared to taking the same action in a collectivist culture.

Second, collectivist cultures put a greater emphasis on relationships, harmony, and within-group cooperation than individualist cultures (Chen, Peng, \& Saparito, 2002). Collectivist cultures encourage within-group resource-sharing, which may enhance positive externalities (knowledge spillovers) in agglomeration. Likewise, collectivism suppresses free riding, mitigates opportunistic behavior, induces individuals to sacrifice for the good of the group, and dampens competition within a group (Earley, 1989; Chen et. al., 2002). Therefore, although agglomerations are generally characterized by intense competition (Krugman, 1991; Sorensen \& Audia, 2000), the severity of competition may vary across contexts. Specifically, the intensity of competition is moderated by culture such that the positive externalities associated with agglomeration are enhanced (diminished) in a collectivist (individualist) culture while the negative consequences of agglomeration are diminished (enhanced). Consequently, firms within an agglomeration may compete less aggressively and be more willing to share knowledge in a country characterized by a collectivist culture.

As with culture, political and economic environments also impact a firm's incentives to agglomerate. In this context, we refer specifically to the uncertainty associated with political and 
economic institutions within a country. Although uncertain institutional environments can discourage firms from making investments in foreign markets the first place (Williamson, 1979; Henisz \& Delios, 2001; Henisz \& Macher, 2004), if firms are to invest in a particular country, they can develop strategies to decrease ex post risk. Choosing whether to agglomerate represents an important strategic tool in dealing with such uncertainty (Martin, Salomon \& Wu, 2007; Salomon \& Wu, 2007).

Political and economic uncertainty can impact a firm's incentives to agglomerate in several ways. First, in politically and economically uncertain environments, a firm can decrease risk by generating more accurate expectations of future states of the environment (Arrow, 1972; Henisz, 2002). To improve expectations, the firm needs a better information set. Because agglomerations generate spillovers of other firms' private knowledge of the political and economic environment (Mariotti \& Piscitello, 1995), a firm may choose to agglomerate to better understand and adapt to anticipated changes the institutional environment. For example, when product-market prices are unpredictable, whether due to a lack of market openness, distortions brought about by regulatory intervention, or inefficient government, the quality of the information that can be gleaned from the market decreases (Hayek, 1945). In such cases, firms have greater difficulty understanding and predicting future economic states and must rely on information from other sources. One important source of such information lies in the knowledge spillovers generated by firms within an agglomeration. This information, transmitted through the interaction among firms within the agglomeration, is likely to be richer and more reliable than information available in the market (Burt, 1992; Uzzi, 1997). Information sharing among geographically proximal firms may therefore help them cope in the presence of economic and political uncertainty. 
Second, a firm may choose to agglomerate in order to increase the power of its industry group vis-à-vis governments and other economic agents. For example, a powerful interest group's collective action affords more opportunities to influence policy changes in its favor (Laffont \& Tirole, 1991; Olson, 1965). In addition, firms may take collective action in response to a threat to their common reputation (North, 1981; Ostrom, 1990; Barnett, 2006). Because geographic proximity enables firms to interact with each other more routinely, firms within an agglomeration may have more power to impact policy makers or to band together to respond to external threats than dispersed firms. As a result, in uncertain political and economic environments, firms may agglomerate in order to better mobilize action, if necessary.

Third, uncertainty may also result from inefficient capital markets. When capital markets are incomplete and financial information is less transparent, banks are reluctant to offer loans to firms whose quality is not readily observable, as unknown quality increases bank risk. In such situations, banks generally rely on social relations and environmental cues (Uzzi \& Lancaster, 2003). With limited resources and information, banks generally restrict loans to firms about which they have better information and with which they share ties-for example, those with shared board members or social connections, or from the same geographic area (Gerlach, 1992; Lamoreaux, 1994). Therefore, in countries with weak external capital markets, firms can obtain financial resources on better terms by signaling their quality to the market. One observable and persuasive signal is whether the firm is associated in some way with other reputable corporations (Stuart, Hoang, and Hybels, 1999). A firm may signal its association with or similarity to other reputable corporations by agglomerating. Because the agglomeration includes many similar and related firms, banks can recognize the common traits of these firms and better infer information about each. As such, banks have better information about the whole. 
Consistent with said intuition, Martin, Salomon and Wu (2007) find that firms are indeed more likely to agglomerate in countries characterized by political and economic uncertainty. However, they do not address the location preferences of foreign entrants. They do not distinguish domestic firms from foreign firms with respect to agglomeration. Foreign firms generally act differently than domestic firms with regard to location choice (Shaver, 1998). These differences may arise for various reasons such as, but not limited to, technological heterogeneity, market segmentation, and the spillover implications associated with foreign entry (Shaver, 1998). For our purposes however, the interesting issue is that foreign firms may act differently than domestic firms because foreign entrants are from nations where the institutional environments differ from those in the host country.

While purely domestic firms face a constant national context, foreign entrants face a more complex environment. On the one hand, subsidiaries of multinational firms are influenced by the forces within the destination country, and as such, subject to the demands of the local market. On the other hand, foreign subsidiaries are managed by a parent that often originates from a very different institutional context (Rosenzweig \& Singh, 1991; Westney, 2005). Foreign subsidiaries are therefore subject to various institutional pressures emanating from both the home, and host, countries. The question remains whether foreign firms, in deciding whether to agglomerate, adapt to the host country environment, or are influenced by characteristics of their home country. Arguments support both contradictory positions.

\section{Hypotheses}

Scholars in the international business literature suggest that foreign firms face disadvantages relative to domestic firms operating in their home environment. This disadvantage has come to be referred to as the 'liability of foreignness' (Hymer, 1960). Firms that invest 
abroad face additional costs due to information asymmetries, cultural differences, coordination difficulties, and local biases (Hymer, 1960; Zaheer, 1995; Caves, 1996; Martin \& Salomon, 2003a). Empirical results consistent with this theory show that foreign firms take longer to set up their operations (Salomon \& Martin, 2007), face higher employee costs (Mincer \& Higuchi, 1988; Lipsey, 1994), are subject to more lawsuits than domestic firms (Mezias, 2002), suffer from lower profitability (Zaheer, 1995), and experience a higher probability of failure (Zaheer \& Mosakowski, 1997).

To overcome the liability of foreignness, it is important for foreign entrants to establish legitimacy in the domestic environment (Kostova \& Zaheer, 1999). One way in which foreign firms may achieve legitimacy in the local market is by adapting to the demands of the local environment, and by imitating the behavior of local firms (Zaheer, 1995; Rosenzweig \& Singh, 1991). With respect to location decisions, this is likely to manifest as an adherence to the cultural and institutional norms of the host environment. Thus, we might plausibly expect firms to be more likely to locate within an economic agglomeration when investing abroad if the host country is characterized by a more collectivist culture, greater economic uncertainty, or greater political uncertainty.

Hypothesis 1a: All else equal, foreign firms will be more likely to locate within an agglomeration if the host country is characterized by a more collectivist culture, greater economic uncertainty, or greater political uncertainty.

Although foreign firms have strong incentives to follow host country norms when making location decisions, foreign entrants are also imprinted by their home country's institutional norms. These norms guide firm strategy and behavior, even when entering new markets (Kogut \& Singh, 1988; Erramilli, 1996). 
One of the basic premises of research in international business is that in order to succeed abroad, a firm must possess some advantageous intangible assets and capabilities (Hymer, 1960; Buckley \& Casson, 1976). Firms generally develop these capabilities in their home country (Caves, 1996; Martin \& Salomon, 2003b). Although these capabilities are born from internal firm resources and routines, they are influenced, and shaped, by the institutional context within the home country (Kogut, 2005).

When firms expand abroad, they transfer advantages developed in the home country to multiple country-markets. Because the practices developed in the home country have been shaped by its institutional environment, firms carry those practices with them to their overseas operations (Kogut, 2005; Dicken, Forsgren, \& Malmberg, 1994; Dicken, 2000). For example, foreign subsidiaries often adopt the routines of its parent (Martin \& Salomon, 2003b). Routines develop over time as a result of ongoing interaction between a firm and its environment (Nelson $\&$ Winter, 1982). Because routines are slow to evolve and difficult to change (Cyert \& March, 1963), they have a stable and durable impact on firm behavior. Consistent with these ideas, empirical evidence shows that firms from different countries differ markedly with respect to their routines, activities, and strategies (Dicken, 2000). Moreover, firms generally rely on, and extend, their domestic organizational practices to foreign markets, especially in the early stages of internationalization (Kogut, 2005).

For these reasons, we might expect foreign entrants to adhere to location patterns similar to those in their home country. Although foreign firms face pressures to conform to the local institutional context, they are also influenced, and shaped, by their experience in the home country, and the systematic patterns of behavior exhibited in that country. Therefore, arguments likewise support the view that firms are likely to locate within an economic agglomeration when 
investing abroad if the home country is characterized by a more collectivist culture, greater economic uncertainty, or greater political uncertainty.

Hypothesis 1b: All else equal, foreign firms will be more likely to locate within an agglomeration if the home country is characterized by a more collectivist culture, greater economic uncertainty, or greater political uncertainty.

\section{RESEARCH DESIGN}

\section{Sample}

We are interested in the impact of the institutional environment on FDI agglomeration patterns. Therefore, an industry characterized by investments in diverse national markets is most appropriate for this study. For this reason, we chose to study the global semiconductor industry, which has two advantages for our purposes. First, semiconductor plants are dispersed worldwide and the industry is global in scope, offering ample variance in foreign investment across countries and institutional environments. Second, given that the semiconductor industry is a high-profile industry, plant investments can be reliably tracked, documented, and compared over time.

We began with a list of plants found in the International Fabs on Disk database. This dataset includes information on 1229 semiconductor plant investments across 39 countries from 1960 to 2004. It identifies the city and country in which each plant is located, the corporate parent, the nationality of the corporate parent, the year of establishment, and the technology used in the plant.

Because we are interested in the location patterns of foreign entrants, we limit our sample to foreign plants - those in which a foreign parent has made a substantive investment in a country other than its own home country. A substantive foreign investment is one in which the foreign parent takes an equity stake of at least 10 percent in a facility abroad (Caves, 1996; Graham \& Krugman, 1995; 
Vukmanic, Czinkota, \& Ricks, 1985). ${ }^{2}$ This yielded an initial sample of 195 foreign investments.

However, we take advantage of the full power of the panel to identify existing agglomerations, and construct our agglomeration measure (described below).

In order to construct the dependent variable (agglomeration) and incorporate data on institutions, we supplemented the International Fabs on Disk data with information from the Getty Thesaurus of Geographic Names, Hofstede's Culture Index (Hofstede, 2001), Henisz's Political Constraint (POLCON) Index (Henisz, 2002), and the Penn World Table. Due to gaps in the data for some countries, our final usable sample reduces to 181 foreign plants established in 22 host countries by 61 parent firms from 14 different home countries for the years 1975-2004. Tables 1 and 2 list all host and home countries in our sample, the number of foreign plant investments in (from) each country, and the number of unique parent firms in (from) each country. ${ }^{3}$

$$
\text { ***Insert Tables } 1 \text { and } 2 \text { about here*** }
$$

\section{Measures}

\section{Agglomeration}

The dependent variable of interest reflects whether a firm chooses to agglomerate when making a new plant investment in a foreign country. In order to identify the global agglomerations in these data ex ante, we took advantage of the full power of the panel (1229 firms from 1960 to 2004) to construct our measure. Consistent with prevailing literature, we identify global agglomerations based on the density of plants in a given locale, and we define an agglomeration as a geographic location with at least five neighboring semiconductor plants that

\footnotetext{
${ }^{2}$ Practically, in our data, we did not have any cases in which the foreign parent held anything less than $50 \%$ of the equity in a foreign plant.

${ }^{3}$ In our data, firms have the option to agglomerate (see the definition of the measure in the section below) in only eight of twenty-two countries. All observations from countries in which no agglomerations exist receive the value of 0 (do not agglomerate) for the dependent variable. When we ran results using only those eight countries in which semiconductor agglomerations are present, the results were equivalent in direction and significance to those presented herein. We therefore report results from the full twenty-two country sample in order to take advantage of all the information at our disposal.
} 
are located within a 60 -mile radius of each other and that are separated by areas of distinct, empty geographic space (Baum \& Haveman, 1997; Alcacer \& Zhao, 2006). ${ }^{4}$ The 60 -mile cutoff is based on Getis (1969) and Martin, Salomon and Wu (2007). ${ }^{5}$

Because we have information regarding the exact year in which each semiconductor plant was built, the agglomeration measure is time-varying, allowing global agglomerations to change as plants are added to the industry. This allows a more precise definition of the construct than previously employed in the literature (e.g., Head, Ries, \& Swenson, 1995; Shaver \& Flyer, 2000). Figures 1 and 2 illustrate how the data were used to identify agglomerations in the United States. In 1980, there were 101 plants and 4 distinct agglomerations in the United States. By the year 2000, there were 237 semiconductor plants and 7 agglomerations. To precisely identify all global agglomerations, we similarly plotted all semiconductor plants throughout the world and repeated these procedures country by country, for each year of data available. We did this by recording the exact latitudes and longitudes of the cities in which the plants were located, as obtained from the Getty Thesaurus of Geographic Names, and plotted them country by country. A mapping of the clusters was created using ArcView software. These mappings formed the basis for the identification of our global agglomerations.

\section{***Insert Figures 1 and 2 here***}

Once each country-specific agglomeration was identified, we needed to determine whether the foreign entrant in question had located its plant within the agglomeration. Using the great-circle distance formula, we calculated, in miles, the distance from the focal semiconductor

\footnotetext{
${ }^{4}$ To test the sensitivity of our results against other manifestations of the dependent variable, we alternatively defined an agglomeration as including ten to fifteen plants. We found that the results presented herein are not sensitive to the alternative manifestations; however, we acknowledge that the results were slightly weaker in statistical significance when the cutoff for an agglomeration was fifteen plants.

${ }^{5}$ When we alternatively defined agglomerations as a collection of firms within radiuses of 0,100 , and 200 miles, the results did not change.
} 
plant to the precise latitude/longitude centroid of the nearest agglomeration. ${ }^{6} \mathrm{With}$ this distance in hand, we calculated a binary agglomeration dependent variable. We define AGGLOMERATE as 1 if an FDI plant was located within 60 miles of the nearest agglomeration, 0 otherwise. ${ }^{7}$

\section{Collectivist/Individualist national culture}

National culture has multiple dimensions (Hofstede, 2001). In this study we focus on the continuum of individualism/collectivism. Though the other cultural dimensions (i.e., uncertainty avoidance, masculinity, power distance, and long-term orientation) describe important features of national culture, they are less relevant to explaining a firm's likelihood to join an agglomeration (see Martin et al., 2007). Moreover, of the cultural factors described by Hofstede (2001), individualism/collectivism has received the greatest construct support and empirical validation (see Schwartz, 1994). ${ }^{8}$

To test the relationship between culture and agglomeration, we therefore use the individualism/collectivism dimension of Hofstede's cultural index (Hofstede, 2001). This dimension focuses on the relationship between an individual and referent others. In a culture characterized by extreme individualism, individual interests supersede those of the group. By contrast, in collectivist cultures, individuals subjugate their own interests to those of the group. In the measure defined by Hofstede (2001), 0 represents an extreme collectivist society and 100 represents an extreme individualist society. Each country receives a time-invariant score. We label this variable INDIVIDUALISM.

\section{Political uncertainty}

\footnotetext{
${ }^{6}$ In contrast to Euclidean distance, which calculates the distance between two points on a plane, the great-circle distance formula calculates, in miles, the shortest distance between two points on the surface of a sphere.

${ }^{7}$ To test the robustness of this measure against other manifestations, we alternatively defined agglomeration cutoffs at 0,100 , and 200 miles. The results were quantitatively and qualitatively similar to those presented herein.

${ }^{8}$ Nevertheless, in results not reported, we explored models including uncertaintly avoidance, masculinity, power distance, and long-term orientation. Consistent with prior studies, we did not find consistent relationships between these cultural factors and the decision to join an agglomeration.
} 
To test the effects of political uncertainty, we need a measure that captures the uncertainty inherent in a country's political institutions. We chose the Political Constraints Index (POLCON) index developed by Henisz (2002). We adopt this measure because it accurately reflects the level of political uncertainty within a country. With greater political checks and balances in place, policies are less likely to change arbitrarily. In such cases, the political environment will be more predictable. We label this measure POLITICAL UNCERTAINTY. The index lies on a continuum from 0 to 1 , where 0 represents the most political uncertainty (in which few, if any, checks and balances exist and leaders may make changes arbitrarily), and 1 represents the least political uncertainty (in which many safeguards are in place). The index is time-varying, and has been used widely to measure political uncertainty (e.g., Henisz \& Delios, 2001; Henisz \& Macher, 2004; Martin et al., 2007).

Economic uncertainty

Scholars in macroeconomics point out that economic change stems from both short-term volatility and long-term growth. Economies grow steadily in the long run because of growth in the supply of labor and capital, and because of technological improvements. However, economies may fluctuate substantially in the near term due to unanticipated external shocks, such as sudden changes in aggregate demand or supply (Froyen, 1999). Given that we are interested in a country's economic uncertainty and not in its stable long-term growth trend, we need a measure that captures economic volatility. An appropriate, and often used, measure of such volatility is the standard deviation of real GDP growth (Ramey \& Ramey, 1995; Blanchard \& Simon, 2001; Stock \& Watson, 2002). We label this variable GDP VOLATILITY. GDP volatility captures economic volatility as a result of economic policy.

\section{Control variables}


We control several country-, firm-, plant-, and agglomeration-specific variables that have the potential to influence agglomeration. First, we control for technological superiority by including a measure of feature size (e.g., Martin \& Salomon, 2003b). The International Fabs on Disk database provides information on the feature size of the semiconductor chip to be manufactured at each plant. Feature size, expressed in microns, measures the width of the conducting channels on a semiconductor chip. The narrower the feature size, the greater the capacity of the device, as more circuits are able to fit on one chip. In this industry, firms compete on the basis of their ability to produce semiconductors with ever thinner features (Malerba, 1985; Schoonhoven, Eisenhardt, \& Lyman, 1990; Eisenhardt \& Schoonhoven, 1996).

Firms with superior technology have an incentive to locate away from the agglomeration in order to avoid information leakage and because they ostensibly benefit less than their competitors from inward knowledge spillovers (Shaver \& Flyer, 2000; Nachum \& Wymbs, 2005). Therefore, we control for the impact of technological superiority on the decision to agglomerate. To capture the extent of technological superiority, we measure the focal plant's feature size relative to other plants within the industry (see Henisz \& Macher, 2004; Salomon \& Martin, 2007). We define RELATIVE FEATURE SIZE as the ratio between the focal plant's feature size and the average feature size of all plants (both domestic and foreign) in the nearest agglomeration that were built prior to the focal plant. ${ }^{9}$ We expect that the more advanced the technology a foreign firm possesses relative to its nearest existing competitors, the more likely it will be to choose not to agglomerate.

In addition, we control for firms' experience in a particular country. We do so because Sorenson and Audia (2000) and Chung and Song (2004) point out that firms with little

\footnotetext{
${ }^{9}$ In countries in which there are no agglomerations, we calculate feature size relative to all other plants in the given country. For the first plant established in a given country, the measure receives the value of 1.
} 
experience in a given country have a greater incentive to agglomerate. Moreover, a firm's prior experience in a particular country will likely affect the location choice of its subsequent investments in that country. We therefore define FIRM EXPERIENCE as a count of the plant investments made, prior to the focal plant, by the parent firm in the host country.

Firms may prefer to locate their plants in an existing agglomeration if they have previously built plants in that agglomeration. We therefore define NUMBER OF OWN PLANTS as a tally of the plants built by the parent firm in the agglomeration nearest to the focal plant. The assumption inherent in including such a variable is that if a given geographic location contains many plants built by the same firm, this location is not only more likely to become an agglomeration, but it is also more likely to attract additional investments by the same firm.

Because joint ventures are managed by multiple parents with potentially competing interests, there may be some systematic variations in the location patterns of such ventures. We therefore control for the joint venture status of the focal plant. Our measure, JOINT VENTURE, is coded as 1 if the plant has two or more substantive corporate parents, and 0 otherwise.

Firms build plants in foreign locations for different reasons. If the purpose of a particular plant is to conduct research and explore new technologies, a firm may have a greater incentive to locate its plant within an agglomeration. Collocating with other plants allows firms to benefit from information spillovers and to access a pre-existing, specialized labor pool (Almeida \& Kogut, 1999), which may be more critical for research and development (R\&D) facilities than for manufacturing facilities. Moreover, locating within an agglomeration helps firms maintain closer ties with other supporting institutions, such as universities and/or government labs. Therefore, we control for whether a plant is a specialized R\&D facility or a manufacturing facility. The variable $R \& D$ FACILITY equals 1 if the plant is a specialized R\&D facility. 
Besides firm-level factors that affect FDI location decisions, characteristics of the agglomeration itself may attract or repel foreign firm investments. For example, when the number of competitors within an agglomeration increases, both market competition and the competition for inputs intensify. Intense competition can discourage foreign firms from locating in that area. Therefore, we define the variable NUMBER OF RIVAL PLANTS as the number of plants (both domestic and foreign) built prior to the focal plant within the nearest agglomeration by firms other than the parent firm.

Some agglomerations are created artificially; that is, they may be established and sponsored by the government. Instead of attracting firms based on competitive market characteristics, these agglomerations are established based on the favorable terms or incentives provided by local or regional governments (e.g., favorable tax rates, tax holidays, industrial science parks). To control for this factor, we include a dichotomous variable, SPONSORED SITE. This variable receives the value of 1 if the location in question is a government-sponsored science park, and/or if the firm received favorable treatment in exchange for choosing the particular location.

In addition to the plant-, firm-, and agglomeration-level controls mentioned above, we add two macro-level country controls: GDP and GDP per capita of the host country. We employ GDP as a measure of market size, both product and physical. GDP is likely to be a correlate not only of the size of the product market (i.e., larger product markets support more semiconductor investment), but also of the physical market size (GDP is a correlate of landmass, $\rho=0.78) .{ }^{10}$ Our measure, GDP, captures the gross domestic product of the host country in which the focal plant is built in a given year, expressed in billions of purchasing power parity U.S. dollars.

\footnotetext{
${ }^{10}$ As an alternative to GDP, we included the actual measure of landmass in square miles in specifications not reported. The results did not change. Because GDP and country size are so highly correlated $(\rho=0.78)$, we were not able to include both measures in the same specification. Additionally, because there was very little variance in the landmass of any country from year to year within our sample, we were not able to include this control with our non time-varying culture variables.
} 
To complement our GDP measure, we include a measure of GDP PER CAPITA, expressed in thousands of purchasing power parity U.S. dollars. Economic geographers have pointed out that firms are likely to build plants in countries with advanced infrastructures and skilled labor (Holl, 2004; McCann \& Shefer, 2003). As a measure of income per person, GDP per capita is therefore a correlate of infrastructure and labor quality. ${ }^{11}$

\section{Statistical Method}

In addition to the control variables mentioned above, we use statistical means to address potential unobserved firm effects that may affect location decisions. Each parent company, for reasons not fully observable, may have varying propensities to agglomerate. If a firm has several foreign plants, it is possible that the error term will not be independent across these observations. In theory, either a fixed-effects or a random-effects model may be used to correct for violation of the error (Greene, 2000). However, in our data, many parent firms exhibit no variance in the dependent variable — including, necessarily, firms with a single foreign plant. Under these conditions, and because we have few observations per firm on average, a random-effects model is preferred (Kennedy, 1998). Accordingly, and given that the dependent variable is binary, we employ a random-effects logit model. The random-effects specification effectively controls for a full range of unobserved parent-company effects and is appropriate when studying agglomeration (e.g., Head et al., 1995; Shaver \& Flyer, 2000).

\footnotetext{
${ }^{11}$ In specifications not reported, we included variables that directly measured the quality of a country's infrastructure (e.g., airports and seaports per square mile, number of highway miles per capita) and the availability of skilled labor (e.g., gross ratio of tertiary education levels, engineering graduates per capita, the number of universities within an agglomeration). Results were qualitatively and quantitatively similar to those presented. However, we could not include many of the individual measures in the same specification because the indicators were highly correlated with each other, and models including them failed to converge. Moreover, the indicators varied very little over time and were highly correlated with both GDP and GDP per capita.
} 
Estimates resulting from the random-effects logit model are a direct monotonic, but nonlinear, function of the underlying variables. A positive coefficient indicates that the variable in question has a positive effect on the parent firm's propensity to agglomerate.

\section{RESULTS}

Descriptive statistics and product moment correlations are presented in Table 3. Correlations are generally as expected and moderate in economic magnitude. Moreover, influence tests did not show evidence of multicollinearity.

***Insert Table 3 about here***

The random effects logit regression results are presented in Table 4. In addition to random parent firm effects, we also include fixed time dummies to control for a general time trend in FDI agglomeration patterns. Although not presented, the time dummies were marginally significant as a set $(\mathrm{p}<.10)$, suggesting that foreign entrants were slightly more likely to locate their production facilities within an agglomeration over time.

***Insert Table 4 about here***

Column 1 presents results for the base model of control variables. The results suggest that foreign entrants are more likely to locate their plants within an agglomeration in which they already have an established presence. Moreover, foreign entrants are more likely to locate jointventure and $R \& D$ plants within an agglomeration, perhaps reflective of the learning objective of these types of investments. The positive and significant coefficient on the number of rival plants implies that increased competition discourages collocation. Foreign firms avoid agglomerations in which there are many competitors. Not surprisingly, government-sponsored science parks and tax incentives attract foreign entrants. Foreign entrants are also more likely to agglomerate in 
bigger and wealthier markets as indicated by the results on GDP and GDP per capita.

Interestingly, and counter to expectations, we are not able to replicate the findings of studies that show that firms with superior technology are less likely to agglomerate (e.g., Shaver \& Flyer, 2000; Nachum \& Wymbs, 2005; Martin, Salomon \& Wu, 2007). Although the relative feature size effects are directionally consistent, they do not significantly differ from zero.

Columns 2 through 4 introduce the host and home country institution variables. We add the individualism measures in column 2 . The negative and significant coefficients on both variables indicate that foreign entrants are impacted by cultural factors in both the home and host countries. Consistent with hypothesis 1a, foreign entrants are more likely to agglomerate when they enter countries characterized by collectivist cultures. The results from column 2 likewise support hypothesis $1 \mathrm{~b}$. Foreign entrants that originate from collectivist cultures are also more likely to agglomerate. Although both sets of hypotheses are supported, the effects are significantly stronger in both statistical and economic magnitude for the host country effects.

The results from column 3 offer additional support for hypothesis 1a. Specifically, foreign entrants are more likely to agglomerate in host countries characterized by greater political uncertainty. Unlike the individualism/collectivism results however, hypothesis $1 \mathrm{~b}$ does not receive support, as political factors in the firm's home country have no significant impact on agglomeration patterns in the host country.

Column 4 introduces the GDP volatility measures. As with political uncertainty, the results on GDP volatility support only hypothesis 1a. This suggests that while foreign firms adapt to host country economic uncertainty, economic conditions in the home country have little impact on the firm's propensity to agglomerate in the foreign market. 
Taken together, the results favor hypothesis 1a over hypothesis $1 \mathrm{~b}$. Foreign entrants seem to adapt to the institutional context of the host country when deciding whether to agglomerate. They are less influenced by home country factors.

\section{Additional Analyses}

In addition to the results described above, we perform additional tests to assess the robustness of our findings and to examine alternative manifestations of the institution measures. First, we include an alternative to individualism/collectivism. Although Hofstede (2001) defined useful cultural dimensions, his sample was comprised solely of employees from IBM, a large U.S. multinational corporation. Several scholars have criticized these measures as biased because of the unrepresentative nature of the sample (Triandis, 1982; Lytle, Brett, Barsness, Tinsley, \& Janssens, 1995; McSweeney, 2002). Alternative measures of culture, which use more representative samples, more comprehensive data, and more precise measures, have since validated the individualism/collectivism dimension originally described by Hofstede. One such alternative, for example, is the Schwartz (1994) index. Schwartz (1994) defined and validated two distinct and orthogonal constructs related to individualism/collectivism, which he referred to as autonomy and conservatism. ${ }^{12}$ Autonomy refers to cultures in which individuals are encouraged to think independently and to pursue individual goals. Conservative cultures value group connections, social relationships, shared goals, social order, and traditions. These cultural dimensions were operationalized using a sample of school teachers and college students from sixty-seven nations. Given the complementarity of the Schwartz measure to that used in this study, it provides not only a sound alternative to individualism/collectivism but also a useful robustness test. Likewise, the correlation between the Schwartz and Hofstede dimensions ( $\rho$ $=.61$ ) is suggestive of their conceptual consistency (Schwartz, 1994, 2004). Therefore, in Table

\footnotetext{
${ }^{12}$ The conservatism index was later labeled embeddedness in Schwartz (2004).
} 
5, we re-estimate the individualism/collectivism results from column 2 in Table 4 using

Schwartz's (1994) autonomy and conservatism indexes. ${ }^{13}$

***Insert Table 5 about here***

Column 1 of Table 5 introduces the host and home country conservatism measures.

Because greater values on this index represent more conservative cultures, positive and significant coefficients would be consistent with hypotheses $1 \mathrm{a}$ and $1 \mathrm{~b}$. The results support hypothesis 1a but not $1 \mathrm{~b}$, partially confirming the results from column 2 in Table 4 . Column 2 introduces host and home country measures of autonomy. The coefficient of the host country culture is negative and significant while that of the home country is not significant. These results likewise favor hypothesis 1a.

\section{***Insert Table 6 about here***}

Second, in Table 6 we re-estimate our models using alternative proxies for political and economic uncertainty. La Porta, Lopez-de-Silanes, Shleifer, \& Vishny (hereafter LLSV) (1998) measured different characteristics of a country's legal system. They argue that specific features of a country's legal system will impact political and economic stability, and thereby, corporate governance. We focus on three specific measures from the LLSV (1998) index that are germane to our context: efficiency of the judicial system, rule of law, and corruption. ${ }^{14}$ Findings that suggest that foreign entrants agglomerate in host countries characterized by an inefficient judicial system, a weak tradition in rule of law, and greater levels of corruption would substantiate the

\footnotetext{
${ }^{13}$ Hofstede (2001) includes culture data for twenty-two of the host countries in our sample. By contrast, Schwartz's (1994) data were available for only thirteen host countries in the sample. The sample therefore decreases from $\mathrm{n}=$ 181 to $\mathrm{n}=143$ when we switch from the Hofstede (2001) index to the Schwartz (1994) index. The results do not change when we use the Hofstede (2001) measures on the smaller sample.

${ }^{14}$ Although the LLSV measure captures twenty-three specific features of a country's legal system, many of the measures focus on the law as it relates to corporate governance rather than on political and economic institutions. For example, constructs measured in LLSV (1998) include creditor rights, mandatory dividends, proxy by mail, etc. In this paper, we are interested in those constructs that are most closely related to macro-level indicators of political and economic uncertainty. We therefore restrict our analysis to efficiency of the judicial system, rule of law, and corruption.
} 
findings from Table 4. Consistent with hypothesis 1a, we find that the host country efficiency and corruption indexes have a significant negative impact on agglomeration. This suggests that foreign entrants are more likely to agglomerate when the legal system is less efficient, less open, and less transparent in the host country. Although the host country rule of law effect is directionally correct, it is not statistically significant. As in Table 4, we likewise do not find support for hypothesis $1 \mathrm{~b}$ for our institutional measures. ${ }^{15}$

Taken together, the results presented in Tables 5 and 6 generally corroborate findings from Table 4. Evidence indicates that foreign entrants agglomerate in host countries characterized by conservative cultures and disperse in host countries characterized by autonomous cultures. Moreover, foreign firms are more likely to agglomerate in host countries characterized by institutional uncertainty. Multinational firms therefore change their patterns of agglomeration across institutional contexts, and host, rather than home, country characteristics seemingly drive those changes.

\section{DISCUSSION AND CONCLUSION}

Although the extant strategy, economics, and international business literatures demonstrate that location choice is dependent upon external market factors and internal firm characteristics, we understand far less about how institutional factors influence those decisions. To fill that gap, this study focuses on the impact of institutions on agglomeration. In particular, we examine the impact of host and home country characteristics on the agglomeration patterns of foreign firms.

\footnotetext{
${ }^{15}$ Although POLCON and GDP Volatility data were available for all twenty-two host countries in our sample, the LLSV data cover only fourteen host countries in the sample. Therefore, the sample size decreases from $\mathrm{n}=181$ to $\mathrm{n}$ $=164$ when we switch to the LLSV data in table 5 . As before, the results do not change when we run the results from Table 4 on the smaller, LLSV-restricted sample.
} 
We argued that foreign firms are likely to behave differently than domestic firms with respect to location preference because the institutional environments in the home country often differ from those in the host country. As such, multinational firms are subject to competing pressures. On the one hand, they are impacted by the institutional environment of the host nation. On the other, they are imprinted by the institutional environments within their home country. This leads to an interesting tension for firms making investments in foreign countries - whether to make location decisions based on patterns exhibited in their home country or based on patterns exhibited in the host country. We examined this question by testing whether plant investments made by foreign firms in a given country were influenced more by host or home country characteristics. We found that the decision to agglomerate was influenced more by the institutional characteristics of the host country than the home country. In fact, home country factors had very little impact on agglomeration decisions in the host countries. Altogether, the findings suggest that foreign firms make more of an effort to adapt to the local host environment.

At this point, we draw several caveats with respect to the findings. First, we acknowledge that our measures of culture are not time-varying. As a result, to the extent that the individualism/collectivism or autonomy/conservatism of a country varies significantly over time, our results may have some bias inhered. However, as Hofstede (2001) has pointed out, national culture remains relatively stable across countries and over time. Nevertheless, if national culture were to change significantly over time, this would make our results a more conservative test of the phenomenon, as results consistent with such a hypothesis would actually indicate an effect greater than that measured. Second, although our data are unique in the length of the panel and in the number of countries in which we observe plant investments, they are limited solely to the semiconductor industry. This industry exhibits some peculiar qualities. For example, because it 
is global in scope, a substantial portion of the products manufactured at local plants may be transported to and sold in the global market, rather than in the local market. Therefore, to the extent that agglomeration patterns are idiosyncratic to this industry, our results may not be as informative for other industries. This may call their generalizability into question. For these reasons, we are hesitant to draw stronger conclusions.

The aforementioned limitations notwithstanding, our findings hold important implications. Our results indicate that the institutional environment can play a significant role with respect to the location choice of multinational firms, and that foreign entrants tend to anticipate such effects when deciding whether to agglomerate. Ultimately, the results demonstrate that the institutional context affects a firm's incentives to agglomerate.

If we assume that location decisions are ultimately tied to performance, future research would be well served to examine the relationship between FDI location choice, its fit with the institutional environment, and performance. Our findings are consistent with those of Kostova and Zaheer (1999), which suggest that adaptation to host country institutional environment may be critical to FDI survival. Therefore, we would expect foreign entrants that agglomerate in host countries with more collectivist cultures, and in those characterized by economic and political uncertainty, to perform better than those that do not.

More broadly, our analyses demonstrate the importance of institutional conditions on location choice, and specifically, the decision to agglomerate with other industry participants. Admittedly, we have presented only a first pass at what is surely a much more complicated phenomenon. Nevertheless, we hope others will follow in exploring the interplay among culture, institutions, and location. Given the theoretical importance of these issues and the significance of our findings, further conceptual and empirical research in this area seems well warranted. 


\section{REFERENCES}

Alcacer, J., \& Zhao, M. 2006. Understanding local clusters through global firms: The semiconductor industry. University of Michigan Working Paper.

Almeida, P., \& Kogut, B. 1999. Localization of knowledge and the mobility of engineers in regional networks. Management Science, 45(7): 905-917.

Arrow, K.J. 1972. The value of and demand for information. In C.B. McGuire \& R. Radner (Eds.). Decision and Organization: 131-139. Amsterdam and London: North Holland.

Barnett, M. 2006. Finding a working balance between competitive and communal strategies. Journal of Management Studies, 43(8): 1753-1773.

Barrell, R. \& Pain, N. 1999. Domestic institutions, agglomerations and foreign direct investment in Europe. European Economic Review, 43: 925-934.

Baum, J.A., \& Haveman, H.A. 1997. Love thy neighbor? Differentiation and agglomeration in the Manhattan hotel industry, 1989-1990. Administrative Science Quarterly, 42(2): 304-338.

Benito, G.R.G., \& Gripsrud, G. 1992. The expansion of foreign direct investments: Discrete rational location choices or a cultural learning process? Journal of International Business Studies, 23(3): 461- 476.

Blanchard, O., \& Simon, J. 2001. The long and large decline in U.S. output volatility. Brookings Papers on Economic Activity, 1: 135-174.

Braunerhjelm, P., \& Svensson, R. 1996. Host country characteristics and agglomeration in foreign direct investment. Applied Economics, 28:833-840.

Buckley, P.J., \& Casson, M. 1976. The Future of Multinational Enterprise. New York: Holmes \& Meier Publishers.

Burt, R. 1992. The social structure of competition. In N. Nohria \& R. Eccles (Eds.). Networks and Organizations: 57-91. Boston: Harvard Business School Press.

Caves, R.E. 1996. Multinational Enterprise and Economic Analysis. New York: Cambridge University Press.

Chen, C.C., Peng, M.W., \& Saparito, P.A. 2002. Individualism, collectivism and opportunism: A cultural perspective on transaction cost economics. Journal of Management, (28)4: 567-583.

Chung, W., \& Song, J. 2004. Sequential investment, firm motives, and agglomeration of Japanese electronics firms in the United States. Journal of Economics and Management Strategy, 13(3): 539-560.

Cyert, R., \& March, J. 1963. A behavioral theory of the firm. Englewood Cliffs, N.J.: Prentice Hall.

Dicken, P. 2000. Places and flows: Situating international investment. In G. L. Clark, M. P. Feldman, \& M. S. Gertler (Eds.), The Oxford handbook of economic geography. New York: Oxford University Press.

Dicken, P., Forsgren, M., \& Malmberg, A. 1994. The local embeddedness of transnational corporations. In Amin A. Thrift N. (Eds.), Globalization, institutions and regional development in Europe. Oxford: Oxford University Press.

DiMaggio, P.J., \& Powell, W.W. 1983. The iron cage revisited: Institutional isomorphism and collective rationality in organizational fields. American Sociological Review, 48(2): 147-160.

Dunning, J.H. 1988. The eclectic paradigm of international production: A restatement and some possible extensions. Journal of International Business Studies, 19(1): 1-31.

Earley, P.C. 1989. Social-loafing and collectivism: A comparison of the United States and the People's Republic of China. Administrative Science Quarterly, 34(4): 565-581.

Eisenhardt, K.M., \& Schoonhoven, C.B. 1996. Resource-based view of strategic alliance formation: Strategic and social effects in entrepreneurial firms. Organization Science, 7(2): 136-150.

Erramilli, M. 1996. Nationality and subsidiary ownership patterns in multinational corporations. Journal of International Business Studies, 27 (2): 225-248.

Fischer, J.H., \& Harrington, J. Jr. 1996. Product variety and firm agglomeration. Rand Journal of Economics, 27(2): 281-309.

Froyen, R.T. 1999. Macroeconomics: Theories and Policies (6th ed.). Upper Saddle River, NJ: Prentice Hall. Gerlach, M. 1992. The Alliance Structure of Japanese Business. Berkeley: University of California Press.

Getis, A. 1969. Residential location and the journey to work. Proceedings, Association of American Geographers 1: 55-59. 
Ghosh, A., \& Rushton, G. 1987. Spatial Analysis and Location-Allocation Models. New York: Van Nostrand Reinhold.

Graham, E.M., \& Krugman, P. 1995. Foreign Direct Investment in the United States (3rd ed.). Washington, DC: Institute for International Economics.

Greene, W.H. 2000. Econometric Analysis. Upper Saddle River, NJ: Prentice Hall.

Hannan, M.T., \& Carroll, G.R. 1992. Dynamics of Organizational Populations: Density, Legitimation, and Competition. New York: Oxford University Press.

Hannan, M.T., Carroll, G.R., Dundon, E.A., \& Torres, J.C. 1995. Organizational evolution in a multinational context: Entries of automobile manufacturers in Belgium, Britain, France, Germany, and Italy.

American Sociological Review, 60(4): 509-528.

Hayek, F.A. 1945. The use of knowledge in society. American Economic Review, 35(4): 519-530.

He, C. 2002. Information costs, agglomeration economies and the location of foreign direct investment in China. Regional Studies, 36(9): 1029-1036.

Head, K., Ries, J., \& Swenson, D. 1995. Agglomeration benefits and location choice: Evidence from Japanese manufacturing investments in the United States. Journal of International Economics, 38: 223-247.

Henisz, W.J. 2002. The institutional environment for infrastructure investment. Industrial and Corporate Change, 11(2): 355-389.

Henisz, W.J., \& Delios, A. 2001. Uncertainty, imitation, and plant location: Japanese multinational corporation, 1980-1998. Administrative Science Quarterly, 46(3): 443-477.

Henisz, W.J., \& Macher, J.T. 2004. Firm- and country-level trade-offs and contingencies in the evaluation of foreign investment: The semiconductor industry, 1994-2002. Organization Science, 15(5): 537-554.

Hofstede, G. 1985. The interaction between national and organizational value systems. Journal of Management Studies, 22(4): 347-357.

Hofstede, G. 1994. Management scientists are human. Management Science 40(1, Focused issue: Is management science international?): 4-13.

Hofstede, G. 2001. Culture's Consequences: Comparing Values, Behaviors, Institutions, and Organizations Across Nations (2nd ed.). Thousand Oaks, CA: Sage Publications.

Hofstede, G., Van Duesen, C.A., Mueller, C.B., Charles, T.A., \& Business Goals Network. 2002. What goals do business leaders pursue? A study in fifteen countries. Journal of International Business Studies, 33(4): 785-803.

Holl, A. 2004. Transport infrastructure, agglomeration economies, and firm birth: Empirical evidence from Portugal. Journal of Regional Science, 44(4): 693-712.

Hotelling, H. 1929. Stability in competition. The Economic Journal, 39(153): 41-57

Hymer, S. 1960. The International Operations of National Firms: A Study of Direct Foreign Investment. Cambridge, Mass: The MIT Press.

Kennedy, P. 1998. A Guide to Econometrics (4th ed.). Cambridge, MA: MIT Press.

Kogut, B., \& Singh, H. 1988. The effect of national culture on the choice of entry mode. Journal of International Business Studies 19(3): 411-432.

Kogut, B. 2005. Learning, or the importance of being inert: Country imprinting and international competition. In S. Ghoshal \& D.E. Westney (Eds.) Organization theory and the multinational corporation: 106-122. New York: Palgrave MacMillan.

Kostova, T., \& Zaheer, S. 1999. Organizational legitimacy under conditions of complexity: The case of multinational enterprise. Academy of Management Review, 24(1): 64-81.

Krugman, P.R. 1991. Geography and Trade. Cambridge, MA: MIT Press

Laffont J-J, Tirole J. 1991. The politics of government decision-making: A theory of regulatory capture. Quarterly Journal of Economics, 106(4): 1089-1127.

Lamoreaux, N.R. 1994. Insider Lending: Banks, Personal Connections, and Economic Development in Industrial New England. New York: Cambridge University

La Porta, R., Lopez-de-Silanes, F., Shleifer, A., \& Vishny, R.W. 1998. Law and finance. Journal of Political Economy, 106(6): 1113-1155.

Lipsey, R. E. 1994. Foreign-owned firms and US wages. NBER Working Paper, 4927. 
Lytle, A.L., Brett, J.M., Barsness, Z.I., Tinsley, C.H., \& Janssens, M.S. 1995. A paradigm for confirmatory cross-cultural research in organizational behavior. Research in Organizational Behavior, 17: 167214.

Malerba, F. 1985. The Semiconductor Business: The Economics of Rapid Growth and Decline. Madison: The University of Wisconsin Press.

Mariotti, S., \& Piscitello, L. 1995. Information costs and location of FDIs within the host country: Empirical evidence from Italy. Journal of International Business Studies, 26(4): 815-841.

Marshall, A. 1920. Principle of Economics. London: Macmillan.

Martin, X., \& Salomon, R. 2003a. Knowledge transfer capacity and its implications for the theory of the multinational corporation. Journal of International Business Studies, 34(4): 356-373.

Martin, X., \& Salomon, R. 2003b. Tacitness, learning, and international expansion: A study of foreign direct investment in a knowledge-intensive industry. Organization Science, 14(3): 297-312.

Martin, X., Salomon, R., \& Wu, Z. 2007. The Cultural and Institutional Determinants of Location Choice: An Examination of Agglomeration in the Global Semiconductor Industry. New York University Working Paper.

Martin, X., Swaminathan, A., \& Tihani, L. 2007. Modeling International Expansion. Forthcoming Research Methodology in Strategy and Management, in D. Ketchen and D. Bergh (Ed.) JAI Press.

McCann, P., \& Shefer, D. 2003. Location, agglomeration and infrastructure. Papers in Regional Science, 83(1): 177-196.

McSweeney, B. 2002. Hofstede's model of national cultural differences and their consequences: A triumph of faith, a failure of analysis. Human Relations, 55(1): 89-118.

Meyer, J.W., \& Rowan B. 1977. Institutionalized organizations: Formal structure as myth and ceremony. American Journal of Sociology, 83: 340-363.

Mezias, J. M. 2002. Identifying liabilities of foreignness and strategies to minimize their effects: The case of labor lawsuit judgments in the United States. Strategic Management Journal, 23: 229-244.

Mincer, J. \& Higuchi, M. 1988. Wage structures and labour turnover in the US and Japan. Journal of the Japanese and International Economies, 2: 97-133.

Morris MH, Davis DL, Allen JW. 1994. Fostering corporate entrepreneurship: Cross-cultural comparisons of the importance of individualism versus collectivism. Journal of International Business Studies 25(1): 65-89.

Nachum L., \& Wymbs, C. 2005. Product differentiation, external economies and MNE location choices: M\&As in global cities. Journal of International Business Studies 36,(4): 415-434.

Nelson, R.R., Winter, S. 1982. An Evolutionary Theory of Economic Change. Cambridge, MA: Belknap Press.

North, D. 1981. Structure and Change in Economic History. New York: Norton

Olson, M. 1965. The Logic of Collective Action. Cambridge, MA: Harvard University Press.

Ostrom, E. 1990. Governing the Commons: The Evolution of Institutions for Collective Action. Cambridge, UK: Cambridge University Press.

Porter, M.E. 2000. Locations, clusters, and company strategy. In Clark GL, Feldman MP, Gertler MS (eds.). The Oxford Handbook of Economic Geography, 253-274. New York: Oxford University Press;.

Ramey, G., \& Ramey, V.A. 1995. Cross-country evidence on the link between volatility and growth. American Economic Review, 85(5): 1138-1151.

Rosenzweig, P.M, \& Singh, J.V. 1991. Organizational environments and the multinational enterprise. Academy of Management Review, 16(2): 340-361.

Salomon, R., \& Martin, X. 2008. Learning, knowledge transfer, and technology implementation performance: A study of time-to-build in the global semiconductor industry. Management Science. Forthcoming.

Salomon, R., \& Wu, Z. 2007. The Institutional and Cultural Determinants of Location Choice. In S. Tallman (Ed.) International Strategic Management: A New Generation: 245-262. Cheltenham, UK: Edward Elgar.

Schoonhoven, C.B., Eisenhardt, K.M., \& Lyman, K. 1990. Speeding products to market: Waiting time to first product introduction in new firms. Administrative Science Quarterly, 35: 177-207.

Schwartz, S.H. 1994. Beyond individualism/collectivism: New cultural dimensions of values. In U. Kim, H.C. Triandis, C. Kagitcibasi, S-C Choi, \& G. Yoon (Eds.) Individualism and Collectivism: Theory, Method and Application: 85-122. Newbury Park, CA: Sage. 
Schwartz, S.H. 2004. Mapping and interpreting cultural differences around the world. In H. Vinken, J. Soeters, \& P. Ester (Eds.). Comparing Cultures: Dimensions of Culture in a Comparative Perspective: 43-73. Leyden: Brill Academic Publishers.

Shaver, J.M. 1998. Do foreign-owned and U.S.-owned establishments exhibit the same location pattern in U.S. manufacturing industries? Journal of International Business Studies, 29(3): 469-492.

Shaver, J.M., \& Flyer, F. 2000. Agglomeration economies, firm heterogeneity and foreign direct investment in the United States. Strategic Management Journal, 2(12): 1175-1193.

Sorenson, O., \& Audia, P.G. 2000. The social structure of entrepreneurial activity: Geographic concentration of footwear production in the United States, 1940-1989. American Journal of Sociology, 106(2): 424-462.

Stock, J., \& Watson, M.W. 2002. Has the business cycle changed and why? National Bureau of Economic Research Working Paper 9127.

Stuart, T.E., Hoang, H., \& Hybels, R.C. 1999. Interorganizational endorsements and the performance of entrepreneurial ventures. Administrative Science Quarterly, 44: 315-349.

Triandis, H.C. 1995. Individualism and Collectivism. Boulder, CO: Westview Press.

Uzzi, B. 1997. Social structure and competition in interfirm networks: The paradox of embeddedness. Administrative Science Quarterly, 42: 35-67.

Uzzi, B., \& Lancaster, R. 2003. Relational embeddedness and learning: The case of bank loan managers and their clients. Management Science, 49(4): 383-399.

Vukmanic, F.G., Czinkota, M.R., \& Ricks, D.A. 1985. National and international data problems and solutions in the empirical analysis of intra-industry direct foreign investment. In Erdilek, A. (Ed.). Multinationals as Mutual Invaders: Intra-Industry Direct Foreign Investment: 160-184.New York: St. Martin's Press.

Westney, D.E. 2005. Institutional theory and the multinational corporation. In S. Ghoshal \& D.E. Westney (Eds.) Organization theory and the multinational corporation: 106-122. New York: Palgrave MacMillan.

Weber, A. 1929. Theory of Location of Industries. New York: Russel and Russel.

Woodward, D.P, \& Rolfe, R.J. 1993. The location of export-oriented foreign direct investment in the Caribbean Basin. Journal of International Business Studies, 24(1): 121-144.

Williamson, O.E. 1979. Transaction cost economics: The governance of contractual relations. Journal of Law and Economics, 22: 233-262.

Zaheer, S. 1995. Overcoming the liability of foreignness. Academy of Management Journal, 38 (2): 341-363.

Zaheer, S., \& Mosakowski, E. 1997. The dynamics of foreignness: a global study of survival in financial services. Strategic Management Journal, 18(6): 439-463. 
FIGURE 1a - Semiconductor Plants in the U.S. (all plants in 1980)

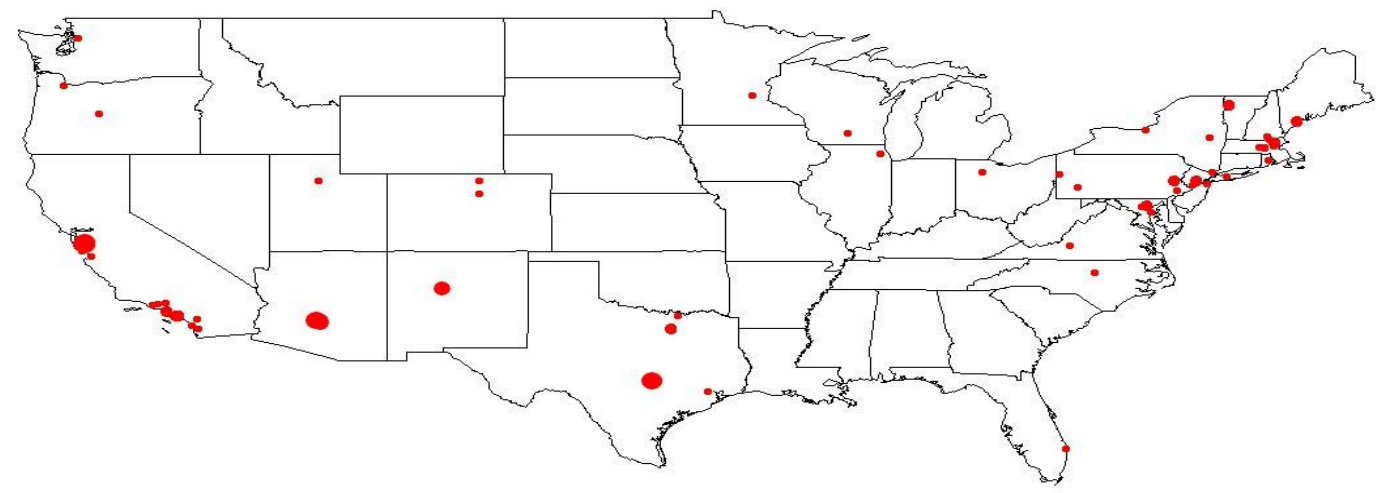

FIGURE 1b - Semiconductor Plants in the U.S. (Agglomerations 1980)

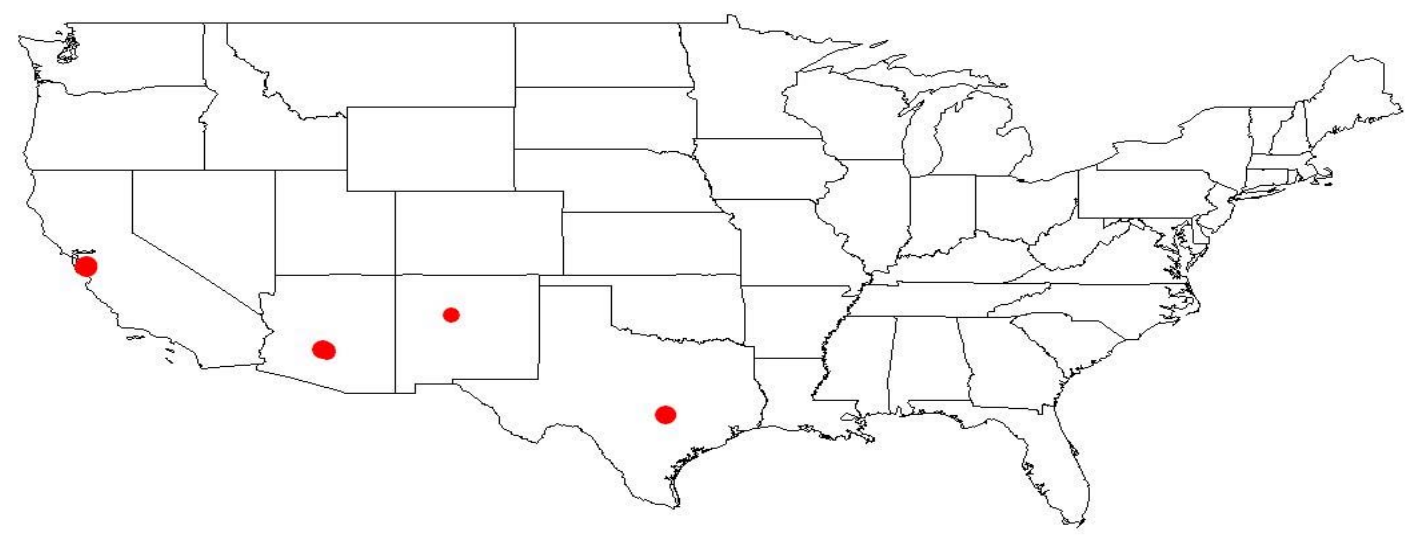


FIGURE 2a - Semiconductor Plants in the U.S. (all plants 2000)

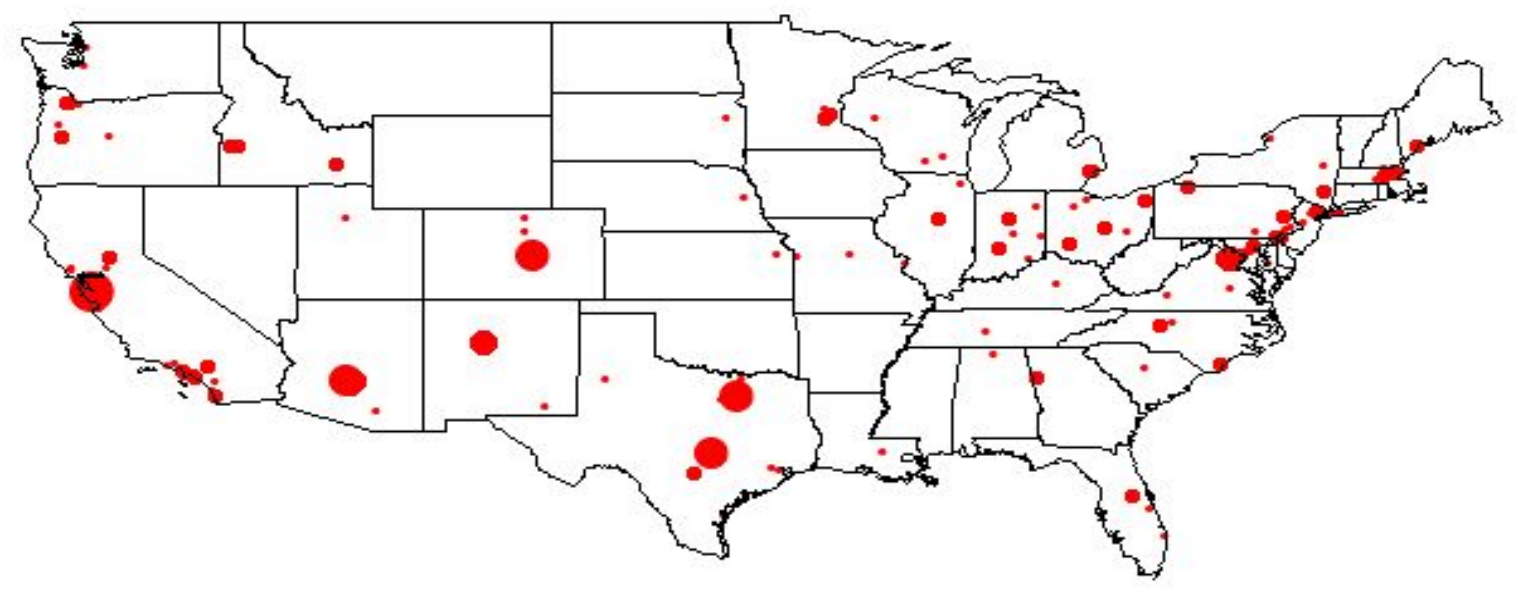

FIGURE 2b - Semiconductor Plants in the U.S. (Agglomerations 2000)

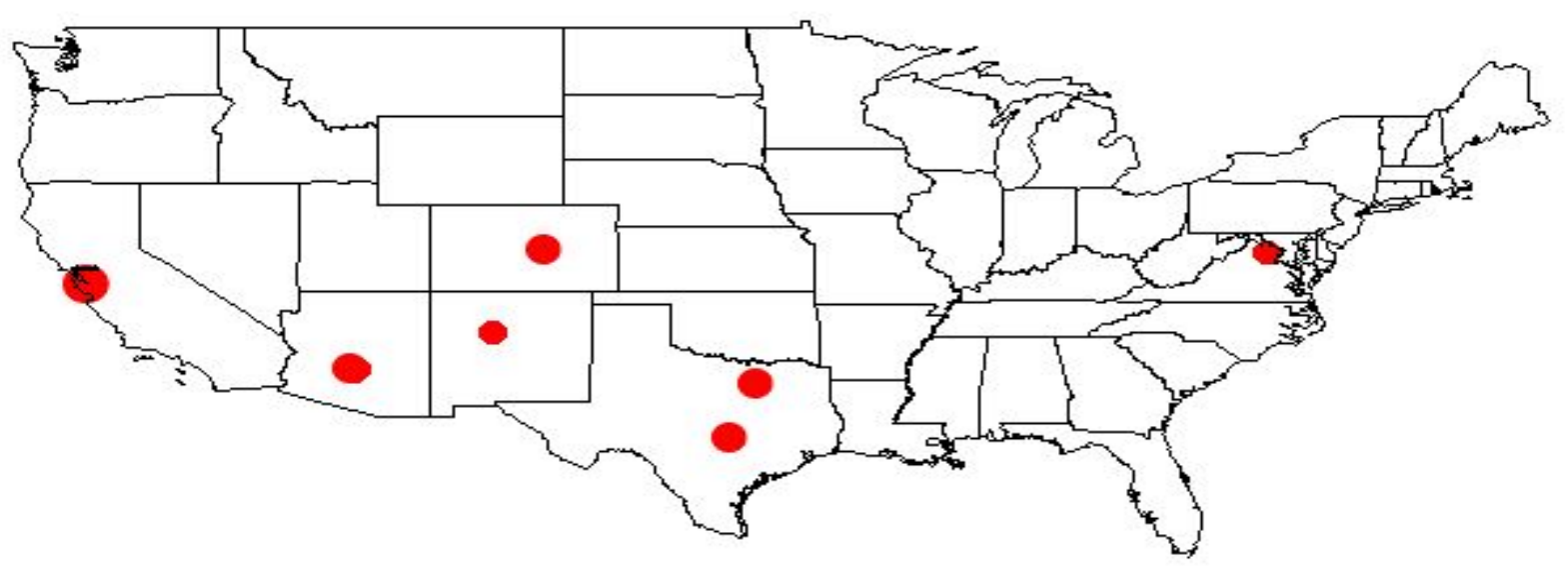


TABLE 1: Host Country Firm and Plant Distributions

\begin{tabular}{rlcc}
\hline \multicolumn{1}{c}{ Host Country } & Number of firms & $\begin{array}{c}\text { Number of } \\
\text { plants }\end{array}$ \\
\hline 1. & Australia & 1 & 1 \\
2. & Austria & 1 & 2 \\
3. & Belgium & 1 & 2 \\
4. & China & 10 & 13 \\
5. & France & 6 & 8 \\
6. & Germany & 14 & 22 \\
7. & Hong Kong & 1 & 1 \\
8. & Ireland & 2 & 4 \\
9. & Israel & 1 & 2 \\
10. & Italy & 1 & 3 \\
11. & Japan & 9 & 27 \\
12. & Malaysia & 3 & 3 \\
13. Netherlands & 2 & 2 \\
14. & Russia & 1 & 1 \\
15. & Singapore & 9 & 20 \\
16. & Slovakia & 1 & 1 \\
17. & South Korea & 1 & 1 \\
18. & Spain & 1 & 1 \\
19. & Sweden & 1 & 2 \\
20. & Taiwan & 5 & 13 \\
21. & United Kingdom & 10 & 19 \\
22. & United States & 20 & 33 \\
\hline
\end{tabular}

TABLE 2: Home Country Firm and Plant Distributions

\begin{tabular}{clcc}
\hline & Home Country & Number of firms & $\begin{array}{c}\text { Number of } \\
\text { plants }\end{array}$ \\
\hline 1. & Australia & 1 & 1 \\
2. & Austria & 1 & 1 \\
3. & Belgium & 1 & 1 \\
4. & Canada & 1 & 5 \\
5. & China & 2 & 3 \\
6. & France & 1 & 2 \\
7. & Germany & 1 & 7 \\
8. & Italy & 1 & 10 \\
9. & Japan & 16 & 35 \\
10. & Netherlands & 1 & 22 \\
11. South Korea & 4 & 7 \\
12. & Switzerland & 1 & 2 \\
13. & Taiwan & 2 & 2 \\
14. & United States & 30 & 83 \\
\hline
\end{tabular}

Note: Total number of plants equals 181 
TABLE 3: Descriptive Statistics and Product Moment Correlations

\begin{tabular}{|c|c|c|c|c|c|c|c|c|c|c|c|c|c|c|c|c|}
\hline & 1. & 2. & 3. & 4. & 5. & 6. & 7. & 8. & 9. & 10. & 11. & 12. & 13. & 14. & 15. & 16. \\
\hline 1. Agglomeration & 1.00 & & & & & & & & & & & & & & & \\
\hline 2. Relative feature size & -0.07 & 1.00 & & & & & & & & & & & & & & \\
\hline 3. Firm experience & 0.18 & -0.09 & 1.00 & & & & & & & & & & & & & \\
\hline 4. Joint venture & 0.49 & -0.13 & 0.12 & 1.00 & & & & & & & & & & & & \\
\hline 5. R\&D facility & 0.09 & 0.20 & -0.03 & -0.02 & 1.00 & & & & & & & & & & & \\
\hline 6. Number of own plants & 0.28 & -0.03 & 0.31 & 0.11 & -0.17 & 1.00 & & & & & & & & & & \\
\hline 7. Number of rival plants & -0.04 & -0.20 & 0.19 & -0.05 & -0.08 & 0.04 & 1.00 & & & & & & & & & \\
\hline 8. Sponsored site & 0.23 & -0.06 & -0.10 & 0.12 & 0.10 & -0.07 & 0.17 & 1.00 & & & & & & & & \\
\hline 9. GDP & 0.07 & -0.11 & 0.24 & -0.07 & -0.05 & -0.17 & 0.30 & 0.11 & 1.00 & & & & & & & \\
\hline 10. GDP per capita & 0.16 & -0.12 & 0.23 & -0.16 & -0.08 & 0.20 & 0.31 & -0.08 & 0.43 & 1.00 & & & & & & \\
\hline 11. Individualism (Host) & -0.40 & 0.08 & 0.04 & -0.53 & -0.01 & -0.16 & 0.07 & -0.24 & 0.48 & 0.46 & 1.00 & & & & & \\
\hline 12. Individualism (Home) & -0.01 & 0.16 & -0.09 & 0.08 & 0.01 & 0.22 & -0.33 & -0.08 & -0.52 & -0.23 & -0.30 & 1.00 & & & & \\
\hline 13. GDP volatility (Host) & 0.11 & 0.01 & -0.13 & 0.03 & 0.01 & 0.04 & -0.06 & 0.00 & -0.17 & 0.07 & -0.06 & -0.02 & 1.00 & & & \\
\hline 14. GDP volatility (Home) & -0.15 & -0.14 & -0.05 & -0.17 & -0.13 & -0.10 & 0.03 & -0.13 & 0.6 & 0.10 & 0.18 & -0.27 & -0.01 & 1.00 & & \\
\hline 15. Political uncertainty (Host) & -0.23 & 0.15 & -0.06 & -0.22 & 0.10 & -0.00 & 0.04 & -0.28 & 0.13 & 0.35 & 0.52 & 0.15 & -0.23 & -0.02 & 1.00 & \\
\hline 16. Political uncertainty (Host) & 0.08 & -0.08 & 0.27 & 0.03 & -0.01 & 0.07 & 0.11 & 0.09 & 0.16 & -0.06 & -0.10 & 0.03 & -0.02 & -0.30 & -0.17 & 1.00 \\
\hline Mean & 0.38 & 0.67 & 9.92 & 0.43 & 0.11 & 0.50 & 11.71 & 0.61 & 23.47 & 19.30 & 57.16 & 73.07 & 0.01 & 0.01 & 0.36 & 0.44 \\
\hline Standard deviance & 0.49 & 0.75 & 9.95 & 0.50 & 0.31 & 0.81 & 13.18 & 0.49 & 25.67 & 7.51 & 27.93 & 22.49 & 0.01 & 0.02 & 0.18 & 0.11 \\
\hline Minimum & 0 & 0.09 & 0 & 0 & 0 & 0 & 0 & 0 & 0.35 & 1.67 & 17 & 17 & 0.00 & 0.00 & 0 & 0 \\
\hline Maximum & 1 & 5.56 & 44 & 1 & 1 & 4 & 65 & 1 & 103.89 & 36.71 & 91 & 91 & 0.06 & 0.14 & 0.71 & 0.69 \\
\hline
\end{tabular}


TABLE 4: Regression Results

\begin{tabular}{|c|c|c|c|c|}
\hline DV: Agglomerate $=1$ & 1. & 2. & 3. & 4. \\
\hline Constant & $\begin{array}{c}-6.42 * * * \\
(-3.69)\end{array}$ & $\begin{array}{c}-2.53 \\
(-1.18)\end{array}$ & $\begin{array}{c}-6.06^{* * * *} \\
(-3.16)\end{array}$ & $\begin{array}{c}-6.28 * * * \\
(-3.87)\end{array}$ \\
\hline Relative feature size & $\begin{array}{c}0.10 \\
(0.26)\end{array}$ & $\begin{array}{c}0.17 \\
(0.39)\end{array}$ & $\begin{array}{c}0.11 \\
(0.26)\end{array}$ & $\begin{array}{c}-0.00 \\
(-0.01)\end{array}$ \\
\hline Firm experience & $\begin{array}{c}-0.01 \\
(-0.19)\end{array}$ & $\begin{array}{l}-0.02 \\
(-0.75)\end{array}$ & $\begin{array}{c}-0.03 \\
(-1.03)\end{array}$ & $\begin{array}{c}-0.01 \\
(-0.21)\end{array}$ \\
\hline Number of own plants & $\begin{array}{c}1.11 * * * \\
(2.71)\end{array}$ & $\begin{array}{c}1.41 * * * \\
(3.02)\end{array}$ & $\begin{array}{c}1.25^{* * *} \\
(3.05)\end{array}$ & $\begin{array}{c}1.13^{* * * *} \\
(2.84)\end{array}$ \\
\hline Joint venture & $\begin{array}{c}2.52 * * * \\
(3.95)\end{array}$ & $\begin{array}{c}1.43^{* * * *} \\
(2.43)\end{array}$ & $\begin{array}{c}2.59 * * * \\
(4.73)\end{array}$ & $\begin{array}{c}2.51 * * * \\
(4.85)\end{array}$ \\
\hline R\&D facility & $\begin{array}{c}1.68 * * * \\
(2.38)\end{array}$ & $\begin{array}{c}2.04 * * * \\
(2.58)\end{array}$ & $\begin{array}{c}1.99 * * * \\
(2.89)\end{array}$ & $\begin{array}{c}1.63 * * * \\
(2.46)\end{array}$ \\
\hline Number of rival plants & $\begin{array}{c}-0.05 * * * \\
(-2.35)\end{array}$ & $\begin{array}{c}-0.06 * * * \\
(-2.83)\end{array}$ & $\begin{array}{c}-0.05 * * * \\
(-2.48)\end{array}$ & $\begin{array}{c}-0.05 * * * \\
(-2.59)\end{array}$ \\
\hline Sponsored site & $\begin{array}{c}2.05 * * * \\
(3.09)\end{array}$ & $\begin{array}{l}0.98^{*} \\
(1.53)\end{array}$ & $\begin{array}{c}1.54 * * * \\
(2.56)\end{array}$ & $\begin{array}{c}2.04 * * * \\
(3.45)\end{array}$ \\
\hline GDP & $\begin{array}{c}0.02 * * \\
(1.69)\end{array}$ & $\begin{array}{c}0.04 * * * \\
(2.68)\end{array}$ & $\begin{array}{l}0.01^{*} \\
(1.30)\end{array}$ & $\begin{array}{c}0.02 * * \\
(2.11)\end{array}$ \\
\hline GDP per capita & $\begin{array}{c}0.09^{* * * *} \\
(2.35)\end{array}$ & $\begin{array}{c}0.19^{* * *} \\
(3.95)\end{array}$ & $\begin{array}{c}0.15^{* * * *} \\
(3.20)\end{array}$ & $\begin{array}{c}0.08^{* *} \\
(2.30)\end{array}$ \\
\hline Individualism (Host country) & & $\begin{array}{c}-0.08 * * * \\
(-4.25)\end{array}$ & & \\
\hline Individualism (Home country) & & $\begin{array}{c}-0.03 * * \\
(-1.76)\end{array}$ & & \\
\hline Political uncertainty (Host country) & & & $\begin{array}{c}-4.67 * * * \\
(-2.69)\end{array}$ & \\
\hline Political uncertainty (Home country) & & & $\begin{array}{c}1.35 \\
(0.58)\end{array}$ & \\
\hline GDP volatility (Host country) & & & & $\begin{array}{c}31.28^{*} \\
(1.59)\end{array}$ \\
\hline GDP volatility (Host country) & & & & $\begin{array}{l}-17.72 \\
(-0.82)\end{array}$ \\
\hline Firm Effects & Included & Included & Included & Included \\
\hline Year Effects & Included & Included & Included & Included \\
\hline $\begin{array}{l}\mathrm{N} \\
\text { Log likelihood (d.f.) }\end{array}$ & $\begin{array}{c}181 \\
-68.96_{(13)}\end{array}$ & $\begin{array}{c}181 \\
-56.68_{(15)}\end{array}$ & $\begin{array}{c}181 \\
-64.28(15)\end{array}$ & $\begin{array}{c}181 \\
-67.35_{(15)}\end{array}$ \\
\hline
\end{tabular}

Note: $* \mathrm{p}<.1 ; * * \mathrm{p}<.05 ; * * * \mathrm{p}<.01$ (one-tailed tests) t-statistics in (parentheses) 
TABLE 5: Regression Results for Schwartz Index

\begin{tabular}{|c|c|c|}
\hline DV: Agglomerate $=1$ & 1. & 2. \\
\hline Constant & $\begin{array}{c}-17.23 * * \\
(-1.80)\end{array}$ & $\begin{array}{c}5.09 \\
(0.59)\end{array}$ \\
\hline Relative feature size & $\begin{array}{c}0.50 \\
(1.05)\end{array}$ & $\begin{array}{l}0.50 \\
(1.08)\end{array}$ \\
\hline Firm experience & $\begin{array}{c}-0.01 \\
(-0.30)\end{array}$ & $\begin{array}{c}-0.01 \\
(-0.43)\end{array}$ \\
\hline Number of own plants & $\begin{array}{c}1.15^{* * *} \\
(2.33)\end{array}$ & $\begin{array}{l}1.20^{* * *} \\
(2.65)\end{array}$ \\
\hline Joint venture & $\begin{array}{c}2.01 * * * \\
(2.93)\end{array}$ & $\begin{array}{l}2.18^{* * * *} \\
(3.40)\end{array}$ \\
\hline R\&D facility & $\begin{array}{c}2.02 * * * \\
(2.24)\end{array}$ & $\begin{array}{l}1.92^{* * *} \\
(2.52)\end{array}$ \\
\hline Number of rival plants & $\begin{array}{c}-0.06^{* *} \\
(-2.19)\end{array}$ & $\begin{array}{c}-0.07^{* * *} \\
(-2.65)\end{array}$ \\
\hline Sponsored site & $\begin{array}{l}1.03^{*} \\
(1.39)\end{array}$ & $\begin{array}{l}1.11^{*} \\
(1.60)\end{array}$ \\
\hline GDP & $\begin{array}{l}0.03 * * \\
(1.93)\end{array}$ & $\begin{array}{c}0.02^{* *} \\
(1.81)\end{array}$ \\
\hline GDP per capita & $\begin{array}{c}0.10^{* * *} \\
(2.19)\end{array}$ & $\begin{array}{c}0.11 * * * \\
(2.57)\end{array}$ \\
\hline Conservatism (Host country) & $\begin{array}{c}3.77 * * * \\
(2.92)\end{array}$ & \\
\hline Conservatism (Home country) & $\begin{array}{c}-0.69 \\
(-0.31)\end{array}$ & \\
\hline Autonomy (Host country) & & $\begin{array}{c}-1.92 * * * \\
(-3.25)\end{array}$ \\
\hline Autonomy (Home country) & & $\begin{array}{c}0.55 \\
(0.55)\end{array}$ \\
\hline Firm Effects & Included & Included \\
\hline Year Effects & Included & Included \\
\hline $\mathrm{N}$ & 143 & 143 \\
\hline$\underline{\text { Log likelihood (d.f) }}$ & $-56.30_{(15)}$ & $-55.14_{(15)}$ \\
\hline
\end{tabular}


TABLE 6: Regression Results for LLSV

\begin{tabular}{|c|c|c|c|}
\hline DV: Agglomerate $=1$ & 1. & 2. & 3. \\
\hline Constant & $\begin{array}{c}-7.29 * * \\
(-1.78)\end{array}$ & $\begin{array}{l}-7.04 * \\
(-1.37)\end{array}$ & $\begin{array}{c}4.50 \\
(0.83)\end{array}$ \\
\hline Relative feature size & $\begin{array}{c}-0.04 \\
(-0.10)\end{array}$ & $\begin{array}{c}0.03 \\
(0.06)\end{array}$ & $\begin{array}{c}0.38 \\
(0.81)\end{array}$ \\
\hline Firm experience & $\begin{array}{c}-0.01 \\
(-0.42)\end{array}$ & $\begin{array}{c}-0.02 \\
(-0.49)\end{array}$ & $\begin{array}{c}-0.01 \\
(-0.21)\end{array}$ \\
\hline Number of own plants & $\begin{array}{c}1.21 * * * \\
(2.68)\end{array}$ & $\begin{array}{c}1.22 * * * * \\
(2.85)\end{array}$ & $\begin{array}{c}1.27 * * * \\
(2.32)\end{array}$ \\
\hline Joint venture & $\begin{array}{c}2.53 * * * \\
(3.91)\end{array}$ & $\begin{array}{c}2.58 * * * \\
(4.30)\end{array}$ & $\begin{array}{c}2.87 * * * \\
(3.71)\end{array}$ \\
\hline R\&D facility & $\begin{array}{c}2.21^{* * * *} \\
(2.80)\end{array}$ & $\begin{array}{c}2.32 * * * \\
(3.02)\end{array}$ & $\begin{array}{c}3.00 * * * \\
(3.07)\end{array}$ \\
\hline Number of rival plants & $\begin{array}{c}-0.05^{* *} \\
(-1.90)\end{array}$ & $\begin{array}{c}-0.03 * * \\
(-1.67)\end{array}$ & $\begin{array}{c}-0.06^{* *} \\
(-2.16)\end{array}$ \\
\hline Sponsored site & $\begin{array}{c}1.87 * * * \\
(2.71)\end{array}$ & $\begin{array}{c}1.79 * * * \\
(2.82)\end{array}$ & $\begin{array}{c}1.79 * * \\
(2.24)\end{array}$ \\
\hline GDP & $\begin{array}{c}-0.02 \\
(-1.02)\end{array}$ & $\begin{array}{c}-0.02 \\
(-0.91)\end{array}$ & $\begin{array}{c}-0.05 * * \\
(-1.83)\end{array}$ \\
\hline GDP per capita & $\begin{array}{c}0.39 * * * \\
(2.85)\end{array}$ & $\begin{array}{c}0.29 * * * \\
(2.75)\end{array}$ & $\begin{array}{c}0.62 * * * \\
(3.30)\end{array}$ \\
\hline Legal efficiency (Host country) & $\begin{array}{l}-0.61^{*} \\
(-1.55)\end{array}$ & & \\
\hline Legal efficiency (Home country) & $\begin{array}{c}-0.04 \\
(-0.13)\end{array}$ & & \\
\hline Rule of law (Host country) & & $\begin{array}{c}-0.21 \\
(-0.42)\end{array}$ & \\
\hline Rule of law (Home country) & & $\begin{array}{c}-0.16 \\
(-0.47)\end{array}$ & \\
\hline Corruption (Host country) & & & $\begin{array}{c}-2.36 * * * * \\
(-3.43)\end{array}$ \\
\hline Corruption (Host country) & & & $\begin{array}{c}-0.54 \\
(-1.10)\end{array}$ \\
\hline Firm Effects & Included & Included & Included \\
\hline Year Effects & Included & Included & Included \\
\hline $\mathrm{N}$ & 164 & 164 & 164 \\
\hline$L_{\text {Log likelihood (d.f.) }}$ & $-56.92_{(15)}$ & $-58.14(15)$ & $-47.99_{(15)}$ \\
\hline
\end{tabular}

